\title{
Non-Muslim Customers' Attitude and Perceptions toward the Products and Services of Islamic Banks: An Exhaustive Study on Islamic Bank Bangladesh Limited.
}

\author{
Md. Bashir Uddin ${ }^{1}$, Anisul Mannan Shammo², Meshkat Mahbub ${ }^{3}$, \\ Neser Ahmed ${ }^{4}$ \\ ${ }^{\text {I }}$ Ph.D fellow, Economics and Management Science, International Islamic University Malaysia, Malaysia) \\ 2,3. (Department of Finance, International Islamic University Malaysia) \\ ${ }^{4}$ (Sr. Lecturer, Sylhet International University, Sylhet, Bangladesh)
}

\begin{abstract}
Islamic banking products and services are gaining popularity among non-Muslims across the globe. The aim of this paper is to examine non-Muslim customers' perception of Islamic banking products and services in Bangladesh. The analysis of this research involved 117 respondents, all of whom are customers of Islamic Bank Bangladesh Limited branches located in Sylhet, Bangladesh. Results of the study indicate that the cheaper transaction costs and better services delivery are the main reasons that attract them to use Islamic banking services. Though majority of the respondents are convinced of the social benefits that can get from the interestfree Islamic banking principles, they are not the primary reasons for their utilization of Islamic banking services in Bangladesh. Furthermore, the findings indicate that majority of non-Muslim customers in Bangladesh perceive current Islamic banking services as suitable in satisfying their banking needs. The authors conclude that non-Muslim customers have positive attitude and perceptions towards the products and services of Islamic banks in Bangladesh.
\end{abstract}

Keywords: Attitude, Islamic banking, Islamic bank services, Islamic bank quality, Non-Muslims.

\section{Introduction}

The word "Attitude" is closely related to the human psychology and it influences human behaviors. Another view is that, an attitude denotes person's consistent evaluation and feelings and tendencies towards an object or idea. It is concerned with people frame of mind in terms of liking and disliking manner (Kotler and Armstrong, 1996:196). Allport (1935) expressed that "Attitude of learned predisposition to respond to an object or class of object is a consistently favorable or unfavorable way". Attitude is mixture of beliefs and feelings that people have about specific ideas, situation or other people. Attitude, which consists of cognitive, affective and behavioral components, reflect how one feels and thinks about some things (Loudon and Bitta, 1984:520). An attitude is the way of thinking, feeling and way of acting toward some aspects of environment (Hawking's, Mothersbongh, and Best, 2007, p-396). The reputed authors found out a new realm to depict the attitude research to imply the new proposition that perception can form the attitude. They also expressed that the perceptual and cognitive responses affect 'attitude'. Besides, Loudon and Bitta (1984) describe the selective perception by which information on services are interpreted that affects the attitudes. Other reputed authors drew an inference that attitude is influenced by perceptual process. Attitude may vary depending on the context of place, time, and persons. Attitude of a person may vary with the community that he or she belongs to and the level of the difference may also vary depending on the situation. So it can be inferred that from the perspective of customer as well as service oriented research, at first, customers perceive the services physically and organize the particular attitude into the mind then to be motivated to decide whether they receive the service for a long time or not.

Bangladesh is one of the third largest Muslim nations in the world. In March 13, 1983 Islamic banking in Bangladesh started business under the banner of Islamic Bank Bangladesh Limited as a pioneer Shariah based Islamic bank. It's now have around 500 branches and also operating in several middle eastern countries. Following the huge success story of Islamic Bank Bangladesh Limited, many banks operated under Shariah principles or by opening Islamic banking windows. From the perspective of competitive banking, bank customers' behavior and attitude toward specific banks and banking services are exclusively significant. At present Islamic banks in the Muslim countries are facing with strong competition not only from Islamic banks but also from non-Islamic rivals. The popularity, now, both Muslim and non-Muslim customers are increasing though the concept of Islamic banking has been developed based on Islamic philosophy. The objective of this study is to know the non-Muslim customer's motivational factors and perception towards the Islamic Banks products and services. Scholars found that there are some studies have been conducted on Islamic Banks, but so 
far our knowledge we have not found any depth studies relating to the topic. So, present study is an ample step to fill the research gap. So, from this perspective, present study has been taken.

\section{Literature Review}

Ahasanul et al., (2009) categorized that the emergence of sturdy Islamic movements in last 3 decades has generated a revived interest in Islamic political economy, particularly in Islamic interest frees banking. Rashid et al., (2008) unconcealed that aboard faith, factors like depositors' need to realize highest come, convenient monetary transactions system, and consistency in commission with uniformity, and better costbenefit implications were substantial to shoppers for selecting their supposed services. It was obviously found that though non secular conviction may be a key think about the employment of Islamic banks merchandise and services, an outsized portion of Muslim folks believed that there's no vital distinction between the merchandise and services by Islamic banks referred as typical banks. In line with Khan, Hassan \& Shahid (2008), the merchandises or services offered by Islamic banks, measure terribly like those of typical banks however the approach of Islamic banks is sort of totally different. Islamic vision of socio-economic justice is predicated on abolishing interest and every one different explicatory components from the economic sphere. Islamic industry facilitates borrowing, loaning and investment functions on a risk-sharing basis (Khan \& Bhatti, 2008). Besides the read of students (economists and monetary analysts), understanding the perception of customers is additionally vital associated understanding associated adapting to client motivation and behavior isn't a possibility however an absolute necessity for competitive survival. Moreover, because the competition within the monetary services trade is additional vigorous than ever as service menu of the companies are getting alike, the necessity for understanding of client behavior of bank customers becomes additional intense. Islamic banks got to vie with some well-established foreign banks like HSBC, customary chartered, and town bank then on. nowadays the competition among the banks isn't restricted to the boundary of the industry. Banks don't seem to be solely competitive industry among every other; however conjointly with non-bank monetary establishments. Therefore, to realize and retain market share, some Islamic banks in Asian country square measure providing some instruments like Murabahah, Ijara that square measure disputed in terms of following law principle. In line with Kuran (2004), the employment of profit and loss sharing instruments, particularly Mudarabah and Musharakah finance have declined to virtually negligible portion. Most of the people in Bangladesh are Muslims and almost 95 percent customers of Islamic banks of Bangladesh are Muslims. Therefore, the breach of Shariah principle might negatively affect customer's attitude toward Islamic banking and thus it will negatively affect the Islamic banking business in Bangladesh. Therefore, the breach of law principle may negatively have an effect on customer's point of view toward Islamic banking and so it'll negatively have an effect on the Islamic banking business in Asian country.

Abdullah, Sidek and Adnan (2012) examined non-Muslim customers' perception of Islamic banking merchandise and services in Asian country. The analysis of this analysis concerned 152 respondents, all of whom square measure primarily based in national capital, Malaysia. The results of the study showed that Islamic banking services square measure creating headway among non-Muslims in national capital. For the degree of perception, the link between faith and education couldn't be established with the perception that the institution of Islamic banking can improve the general banking facilities since most of the respondents were unsure of Islamic banking merchandise and services square measure gaining quality among non-Muslim. Most respondents powerfully thought that Islamic banking would dominate typical banking in Asian country, within the close to future. Despite this positive trend, additional efforts ought to be energized to reinforce the amount of understanding for non-Muslim customers on the Islamic banking ideas.

Hidayat and Al-Bawardi (2012) conducted a survey to judge the perceptions of non-Muslim expatriates in Saudi Arabia toward Islamic banking merchandise and services. knowledge gathered through selfadministered questionnaires from non-Muslim expatriate bank customers $(n=103)$ in Saudi Arabia was used for the study. Results of the study indicate that everyone the respondents square measure alert to and have or had previous Islamic banking exposures. The study conjointly reveals that cheaper dealing prices and higher service delivery square measure the most reasons that attract them to use Islamic banking services. although majority of the respondent's square measure convinced of the social edges which will accrue from the interest-free Islamic banking principles, but they're not the first reasons for his or her utilization of Islamic banking services in Asian country. what is more, the findings indicate that majority of non-Muslim customers in Asian country understand current Islamic banking services as numerous and appropriate in satisfying their banking wants.

\section{Methodology}

An exploratory analysis style is adopted for the study which is supported by the literature review, numerous banking service factors that delight the purchasers within the industry are known and won't to develop the questionnaire. The primary data for the research is gathered by means of a self-administered questionnaire. The questionnaire consists of two parts. Part 1 seeks information on the following demographic 
Non-Muslim Customers' Attitude and Perceptions towards the Products and Services of Islamic ..

factors: age, level of monthly income, level of education, profession and religion. Part 2 is formulated to gather the respondents' perceptions about Islamic banking features, such as the universal goodness of Islamic banking principle of prohibiting interest, the source of information about the Islamic banking services, the nature of Islamic banking services and his/her perceptions about the quality and benefits of Islamic banking services. The responses for perception analysis are sought on a five-point quality type: Likert-scale ranging from " 1 " to " 5 " (with "1" meaning "very poor" and "5" meaning "very good"). Secondary data for the research is collected through published articles, journals and bank records.

The population of the study comprises of non-Muslim bank customers in Bangladesh. The criteria that is set for the selection of the respondents is that they should be adults (18 years old and above) who use and understand the services offered by banks and who may be mature enough to think critically about Islamic banking and its principles. A comprehensive list of non-Muslim bank customers could not be obtained from the bank due to confidentiality reason. Hence, the study adopts a non-probability sampling method, instead of a probability sampling.

A total of 150 questionnaires are distributed to the non-Muslim bank customers in Bangladesh. Completed questionnaires were later screened for errors, incomplete or missing responses. After the final screening process, 117 responses were effectively considered complete and valid for data analysis. This represents a response rate of $78 \%$, which can be considered to be good in view of the time and cost constraints.

Descriptive analyses are conducted to create and represent the respondents' demographic profiles and perception analysis is conducted to evaluate the non-Muslim customers' perceptions about the Islamic banking services.

\section{Demographic Profiles}

\section{Findings And Analysis}

The age analysis of the respondents was done to identify the age group of non-Muslim customers using the Islamic banking services in the Bangladesh. The age profile of the respondents indicates that a majority of the non-Muslim customers are in the age group of 31-40 years (43\%), followed by $40 \%$ of the customers falling in the age group of 41-50 years and 15\% of the customers are in the age group of 21-30 yrs. Table 1 describes the age of respondents in this study.

Table 1: Age of Respondents

\begin{tabular}{|l|l|l|}
\hline & Frequency & Percentage \\
\hline $21-30$ years & 17 & 15 \\
\hline $31-40$ years & 51 & 43 \\
\hline $41-50$ years & 47 & 40 \\
\hline Above 50 years & 2 & 2 \\
\hline Total & 117 & 100.00 \\
\hline
\end{tabular}

The educational profile of the respondents was analyzed to identify the level of ability to understand the principles of Islamic banking or the ability of the consumers to search for the information related to Islamic banking. The finding indicates that about $44 \%$ of the respondents in the study have a Bachelor degree, while $29 \%$ of them have a Master's degree and about $17 \%$ of them have a Diploma. About $10 \%$ of the respondents have only a high school certificate. The finding also indicates that a majority of the respondents have the ability to understand the principles of Islamic banking and to differentiate between Islamic and nonIslamic banking operations. Table 2 describes educational profile of the respondents.

Table 2: Educational Qualification

\begin{tabular}{|l|l|l|}
\hline & Frequency & Percentage \\
\hline High school & 12 & 10 \\
\hline Diploma & 20 & 17 \\
\hline Bachelor degree & 51 & 44 \\
\hline Master degree & 34 & 29 \\
\hline Total & 117 & 100.00 \\
\hline
\end{tabular}

The profession of the respondents was analyzed as part of the demographic analysis to profile the types of non-Muslim customers using the Islamic banking services at Bangladesh. The finding indicates that about $60 \%$ of the respondents are working for private sector firms, while $25 \%$ of them work for government or ministry departments. About $13 \%$ of the respondents are working in family-owned firms while two of the respondents is found to be temporarily without a job. The finding indicates that a majority of the respondents are working in private sector firms. Table 3 describes the job profile of the respondents. 
Non-Muslim Customers' Attitude and Perceptions towards the Products and Services of Islamic ..

Table 3: Job Profile

\begin{tabular}{|l|l|l|}
\hline & Frequency & Percentage \\
\hline Unemployed & 2 & 2 \\
\hline Government employee & 29 & 25 \\
\hline Private sector employee & 71 & 60 \\
\hline Family-owned business & 15 & 13 \\
\hline Total & 117 & 100.00 \\
\hline
\end{tabular}

The annual income of the respondents was analyzed to identify the possible savings' capabilities and the nature of banking services they usually prefer. The finding indicates that a majority of the customers have an annual income between Taka 201,000 to 250,000 (33\%), followed by $28 \%$ of the customers having an annual income of Taka 151,000 to 200,000 . About $25 \%$ of the respondents have an annual income between Taka 101,000 to 150,000, while 9\% have an annual income between Taka 51,000 to 100,000 and 3\% have an annual income greater than Taka 250,000. The finding indicates that a majority of the customers are capable of having a good bank savings as well as the ability to invest in time deposits. Table 4 describes the income profile of the respondents.

Table 4: Income Profile

\begin{tabular}{|l|l|l|}
\hline Annual income (Taka) & Frequency & Percentage \\
\hline$<50,000$ & 2 & 2 \\
\hline $51,000-100,000$ & 11 & 9 \\
\hline $101,000-150,000$ & 29 & 25 \\
\hline $151,000-200,000$ & 33 & 28 \\
\hline $201,000-250,000$ & 38 & 33 \\
\hline$>250,000$ & 4 & 3 \\
\hline Total & 117 & 100.00 \\
\hline
\end{tabular}

Though Bangladesh is a Muslim nation, it has multi-religious workforces. The religion of the respondents was analyzed to identify the distribution of the non-Muslim customers who are utilizing the Islamic banking services. The finding indicates that about $70 \%$ of these non-Muslim respondents are Hindus, followed by $24 \%$ Buddhists. About $4 \%$ of the respondents are Christians. About $2 \%$ of the nonMuslim customers are followers of other religion. The analysis of the respondent's religious affiliations provides banks with profiles of other religions that are practiced in Bangladesh hence helps them to understand the cultural background of the non-Muslim customers. Knowledge of the religious beliefs and customs of potential non-Muslim bank customers will facilitate improved planning, designing and positioning of Islamic banking services in Bangladesh. Table 5 describes the religion profile of the respondents.

Table 5: Religion Profile

\begin{tabular}{|l|l|l|}
\hline Religions & Frequency & Percentage \\
\hline Hindu & 82 & 70 \\
\hline Christian & 5 & 4 \\
\hline Buddhist & 28 & 24 \\
\hline Other & 2 & 2 \\
\hline Total & 117 & 100.00 \\
\hline
\end{tabular}

The study also identified the most common sources of information used by non-Muslim respondents to obtain information about Islamic banking and the nature of its services. A large majority of the non-Muslims $(44 \%)$ respondents reported that they obtained the information about the Islamic banking principles, nature of services and the bank branches from the customer service department of the banks. About $33 \%$ of the respondents reported that they came to know about Islamic banking from their friends and relatives. About $12 \%$ of the respondents were aware about Islamic banking services from TV commercials and Internet.11\% percent of the respondents reported that they learned about the principles of Islamic banking services from articles in journals and newspapers. Therefore, they are already aware about Islamic banking prior to their exposure to Islamic banking services. Table 6 describes the sources of information about Islamic banking services for the respondents.

Table 6: Islamic Banking Information Sources

\begin{tabular}{|l|l|l|}
\hline Sources & Frequency & Percentage \\
\hline Banks & 52 & 44 \\
\hline Newspapers and articles & 13 & 11 \\
\hline Friends and relatives & 38 & 33 \\
\hline Internet and TV & 14 & 12 \\
\hline Total & 117 & 100.00 \\
\hline
\end{tabular}


The respondents were asked to identify the nature of Islamic banking services used by them frequently. About $35 \%$ of the respondents reported that they utilized the Islamic corporate banking services mainly due to the requirements of their workplace or employers. About $33 \%$ of the respondents reported that they had used Islamic banking mainly for investment services. These respondents had used the Islamic mode of investments for higher gain. And $17 \%$ of the respondents had used the Islamic banking services to operate their regular savings and current accounts. About $4 \%$ of the respondents had utilized the Islamic venture capital services and $11 \%$ had availed interest-free personal financing from the banks in Bangladesh. Table 7 describes major Islamic banking services used by the respondents.

Table 7: Major Islamic Banking Services Used

\begin{tabular}{|l|l|l|}
\hline & Frequency & Percentage \\
\hline Savings and current account & 20 & 17 \\
\hline Investments & 39 & 33 \\
\hline Corporate services & 41 & 35 \\
\hline New venture capital & 5 & 4 \\
\hline Personal financing & 12 & 11 \\
\hline Total & 117 & 100.00 \\
\hline
\end{tabular}

The respondents were asked to indicate the percentage of the usage of Islamic banking services to total banking services they regularly use. The finding indicates that a large majority of the respondents (70\%) use Islamic banking services to an extent of 21\%-30\% from the total banking transactions. And $24 \%$ of the respondents reported that Islamic banking transactions constituted less than $20 \%$ of their total banking transactions. Only $6 \%$ of the respondents reported that about $31 \%-50 \%$ of their banking transactions were Sharia-compliant while traditional banking transactions constituted the remainder. This indicates that a majority of the respondents are using the Islamic banking services at a low level compared to conventional forms of banking. This also indicates that conventional banking is still dominant or predominant used by the non-Muslims in Bangladesh. Table 8 describes the extent of Islamic banking services used by respondents.

Table 8: Extent of Islamic Banking Services Used by Respondents

\begin{tabular}{|c|c|c|}
\hline & Frequency & Percentage \\
\hline$<10 \%$ & 0 & 0 \\
\hline $11-20 \%$ & 28 & 24 \\
\hline $21-30 \%$ & 82 & 70 \\
\hline $31-40 \%$ & 5 & 4 \\
\hline $41-50 \%$ & 2 & 2 \\
\hline$>50 \%$ & 0 & 0 \\
\hline Total & 117 & 100.00 \\
\hline
\end{tabular}

The number of years of experience of using Islamic banking services among the respondents is important as it will provide them the ability to rate and compare the Islamic banking services with conventional banking services. The analysis indicates that a majority (53\%) of the non-Muslim respondents have about 1-5 years' experience in using Islamic banking services. And $28 \%$ of the respondents have used the Islamic banking services for about 6-10 years while $15 \%$ have less than 1-year experience of using the services. Only two of them have more than 15 years' experience of using the Islamic banking services. The finding indicates that a majority of the respondents have substantial experience of using Islamic banking services and therefore possess the ability to rate and make a critical judgment about the quality of Islamic banking services offered in Bangladesh. Table 9 describes the number of years of the respondents using Islamic banking services.

Table 9: Years of Using Islamic Banking Services

\begin{tabular}{|l|l|l|}
\hline & Frequency & Percentage \\
\hline$<1$ year & 18 & 15 \\
\hline $1-5$ years & 62 & 53 \\
\hline 6-10 years & 33 & 28 \\
\hline $11-15$ years & 2 & 2 \\
\hline$>15$ years & 2 & 2 \\
\hline Total & 117 & 100.00 \\
\hline
\end{tabular}

The respondents were asked to indicate the primary reasons for using the Islamic banking services. The objective is to find the factors which motivate the respondents to use the Islamic banking services offered. The finding indicates that although a majority of the respondents are convinced about the social good of interest-free banking, this is not the primary reason for them to select the Islamic banking services. The finding indicates that a majority of the respondents prefer to use the Islamic banking services mainly because they found it cheaper as compared to the conventional interest-based banking services. About $58 \%$ of the 
Non-Muslim Customers' Attitude and Perceptions towards the Products and Services of Islamic ..

respondents' reported that they prefer to use Islamic banking services as the service charges are less compared to conventional banking services. The relatively low service charges are the main reasons that a large majority of non-Muslim customers use Islamic banking services. About 38\% of the respondent's report that the good service quality is the reason behind their usage of Islamic banking services. They found the Islamic banking staff more professional and found the speed and quality of services delivered at Islamic banks better than conventional banks. Only $2 \%$ of the respondents are compelled by ideological reasons and prefer to use Islamic banking services mainly because of its policy of avoidance of interest. About $2 \%$ of the respondents' report that the presence of a number of Islamic bank branches in their residential and factory locations make it more convenient for them to use Islamic banking services. Table 10 describes reasons for using Islamic banking services.

Table 10: Reasons for Using Islamic Banking Products and Services

\begin{tabular}{|l|l|l|}
\hline & Frequency & Percentage \\
\hline Philosophy & 2 & 2 \\
\hline Better service & 45 & 38 \\
\hline Cheaper cost & 68 & 58 \\
\hline More branches & 2 & 2 \\
\hline Total & 117 & 100.00 \\
\hline
\end{tabular}

\section{Perception Analysis}

Before the perception analysis is conducted, the respondents are asked if they have any awareness about the Islamic banking, its nature of operations and the basic principles of Islamic banking. The finding indicates that $100 \%$ of the respondents are aware of the nature of Islamic banking services and its guiding principles of interest-free banking transactions and equitable sharing of risks and rewards.

The respondents are asked how convinced they are that the prohibition of interest is good for society and that this driving force behind the Islamic banking services makes it different from conventional banking. About $42 \%$ of the respondents' reported that they are highly convinced with the prohibition of interest as good for society, about $34 \%$ of the respondents' reported that they are moderately convinced, about $13 \%$ of the non-Muslim respondents were not convinced with the Islamic banking principle and $2 \%$ of them were strongly unconvinced about the social benefits of the prohibition of interest. Table 11 describes the respondents' perceptions toward prohibition of interest.

Table 11: The Perception of Respondents about the Prohibition of Interest

\begin{tabular}{|l|l|l|}
\hline & Frequency & Percentage \\
\hline Very poorly & 2 & 2 \\
\hline Poorly & 15 & 13 \\
\hline Neutral & 10 & 9 \\
\hline Moderately & 40 & 34 \\
\hline Highly & 50 & 42 \\
\hline Total & 117 & 100.00 \\
\hline
\end{tabular}

The respondents were asked to rate the quality of Islamic banking services offered to them at the Islamic bank branches. The objective was to identify the non-Muslim customers' perceptions about the quality of banking services offered by Islamic banks in Bangladesh. Nearly 53\% of the respondents rated the overall quality of services delivered at the Islamic banks as good. About 33\% of the respondents rated the overall quality of services delivered at Islamic banks as very good. There are 4 respondents who are not satisfied with the quality of services of Islamic banks in Bangladesh. Table 12 describes quality rating of Islamic banking services.

Table 12: Quality Rating of Islamic Banking Services

\begin{tabular}{|l|l|l|}
\hline & Frequency & Percentage \\
\hline Very poor & 2 & 2 \\
\hline Poor & 2 & 2 \\
\hline Cannot decide & 13 & 10 \\
\hline Good & 62 & 53 \\
\hline Very good & 38 & 33 \\
\hline Total & 117 & 100.00 \\
\hline
\end{tabular}

The respondents were asked to rate their satisfaction with regard to the perceived benefits they avail from Islamic banking services. The objective was to identify the satisfaction levels of non-Muslim customers with the Islamic banking services. 57\% of the respondents rated the benefits of Islamic banking services as good, $28 \%$ rated the benefits accrued from Islamic banking as very good and about $11 \%$ rated it as poor. The 
Non-Muslim Customers' Attitude and Perceptions towards the Products and Services of Islamic ..

finding indicated that a majority of the customers perceived the Islamic banking services as being beneficial. This indicated a higher level of customer satisfaction and a positive image of Islamic banking services among nonMuslim customers in Bangladesh. Table 13 describes perceived benefits of Islamic banking services.

Table 13: Perceived Benefits of Islamic Banking Products and Services

\begin{tabular}{|l|l|l|}
\hline & Frequency & Percentage \\
\hline Very poor & 2 & 2 \\
\hline Poor & 10 & 9 \\
\hline Cannot decide & 5 & 4 \\
\hline Good & 67 & 57 \\
\hline Very good & 33 & 28 \\
\hline Total & 117 & 100.00 \\
\hline
\end{tabular}

The respondents were asked to identify if the Islamic banking services offered by the banks in Bangladesh were applicable to all forms of banking needs of individual customers and corporate customers. The objective was to identify the non-Muslim consumers' perceptions about the range of Islamic banking services in catering to their banking needs. The finding indicates that about $44 \%$ of the respondents feel moderately that the range of available Islamic banking services satisfy their banking needs. About $33 \%$ of the respondents feel very satisfied with the range of available Islamic banking services. In contrast, about $11 \%$ of the respondents perceive that the range of Islamic banking services is poor while $3 \%$ felt very poor and deficient in meeting their banking needs. The finding indicates that a majority of non-Muslim customers in Bangladesh perceive current available Islamic banking services as diverse and suitable in satisfying their banking needs. Table 14 describes perceived applicability of Islamic banking services according to respondents' responses.

Table 14: Perceived Applicability of Islamic Banking Products and Services

\begin{tabular}{|l|l|l|}
\hline & Frequency & Percentage \\
\hline Very poorly & 4 & 3 \\
\hline Poorly & 13 & 11 \\
\hline Cannot decide & 10 & 9 \\
\hline Moderately & 52 & 44 \\
\hline Highly & 38 & 33 \\
\hline Total & 117 & 100.00 \\
\hline
\end{tabular}

\section{Conclusion}

Based on the findings, it can be concluded that Islamic services and products are well-received by nonMuslims population especially in Sylhet, Bangladesh. Results of the study indicate that the Islamic banking principle of avoidance of interest is not the major motivating factors for the non-Muslim customers in Bangladesh to use Islamic banking services. They choose Islamic banking products and services because of cheaper costs and better quality and nature of services. A majority of these non-Muslim customers perceive the benefits of Islamic banking as good and satisfactory.

Since a majority of the respondents' express satisfaction at the quality and professional nature of services offered by the Bangladeshi Islamic bank, the bank has to seriously look at exploiting this segment of customers by tailoring non-Muslim customer acquisition strategies accordingly to make sure that more and more non-Muslim customers use Islamic banking services. Frequent workshops should be arranged to explain the philosophy and functioning of Islamic banking products/services in order to increase their awareness. Incentives in the form of free registration, lower banking transactions cost, free gifts should be offered to the new and existing non-Muslim customers. In addition, more publications on Islamic banking subject should be made publicly available in order to raise the level of understanding and awareness as well as to enhance the level knowledge amongst non-Muslims on Islamic banking concept and operations. In a nutshell, the Islamic banks themselves, which has been in existence for more than 25 years in Bangladesh, should take a more proactive and aggressive efforts such as frequent product campaign and collaboration with schools to promote their banking products and services to non-Muslims.

\section{References}

[1]. Abdullah, A. A., Sidek, R., \& Adnan, A. A. (2012). Perceptions of Non-Muslims Customers towards Islamic Banks in Malaysia. International Journal of Business and Social Science, 3 (11), 151-163.

[2]. Ahasanul Haque et al (2009). Issues of E-Banking Transaction: An Empirical Investigation on Malaysian Customers Perception. Journal of applied Sciences. (Retrived from www.ebsco.com on 20 April 2014).

[3]. Allport, G.W. (1935). Attitudes. In C. Murchison (Ed) Handbook of Social Psychology, Worcester, Mass: Clark University Press.

[4]. Hawkins, D., Mothersbaugh, D., \& Best, R. (2007). Consumer Behavior: Building Marketing Strategy. 10th edition.

[5]. Hidayat, S. E., \& Al-Bawardi, N. K. (2012). Non-Muslims' Perceptions Toward Islamic Banking Services in Saudi Arabia. Journal of US-China Public Administration, 9 (6), 654-670. 
Non-Muslim Customers' Attitude and Perceptions towards the Products and Services of Islamic ..

[6]. Khan, M M \& Bhatti, M I, 2008, 'Development in Islamic Banking: A Financial Risk-allocation Approach', The Journal of Risk Finance, vol. 9, Issue, 1, pp. 40-51

[7]. Khan, M.S.N., Hassan, M. K., \& Shahid, A. I. (2008). Banking behavior of Islamic bank customer in Bangladesh. Journal of Islamic Economics, Banking and Finance, 159-194.

[8]. Kuran, Timur 2004 Islam and Mammon: the economic predicaments of Islamism. Princeton, N.J.: Princeton University Press.

[9]. Loudon, D.L., and A.J. Della Bitta (1984), Consumer Behavior (2nd ed.), New York: McGraw-Hill.

[10]. Philip Kotler and Gary Armstrong, Principles of Marketing, 7th edition, Prentice Hall, 1996

[11]. Rashid, M, Hassan, M. K. and Ahmad, A. U. F. (2008), Quality Perceptions of the Customers towards Domestic Islamic banks in Bangladesh, Journal of Islamic Economics, Banking and Finance, Vol. 5, No. 1, pp. 109-131. 